\title{
BOUNDARIES OF CONSTITUTIONAL AND LEGAL REGULATION OF ECONOMIC RELATIONS
}

\author{
Dmytro Bielov ${ }^{1}$, Olga Sidorenko²
}

\begin{abstract}
It is found that the constitutional and legal norms undoubtedly have a significant impact on the economic system of any state. Models of the world's economic systems are established and guaranteed by a system of legal means, which, in turn, are subject to the constitutional and legal framework. It is specified that the sphere of constitutional and legal regulation of economic relations has been repeatedly explored in scientific research, however, the consensus on the scope of economic issues that should be subject to constitutional entrenchment has not been reached yet. The analysis of the world constitutional practice shows a tendency of strengthening the regulation of those relations that concern the economic organization of public life. This topic is relevant since not only the legal theory but also political practice enters into a heated debate over the above-mentioned issue. The authors argue that: 1) constitutional law regulates the place of the state in the political system of society and defines the principles of relations between the state and its non-state elements including the ways of resolving conflicts between them, limits of interference or even limits of its activity; 2 ) the boundaries of constitutional and legal regulation of economic relations should be determined, first of all, on the basis of considering fundamental relations for the economic system of the state, that is, the limits of constitutional regulation depend on the system of relations that are included in the concept of economic relations; 3 ) the system of relations that require constitutional and legal regulation should also include the establishment of an effective pricing mechanism, the exercise of control over monetary policy, the cancellation of restrictions on foreign trade activities, the development of an effective tax and budgetary system, regulation of financial reporting, etc.
\end{abstract}

Key words: economic system, economic relations, constitutional law, public life, state, political system.

JEL Classification: P10, P26, P43

\section{Introduction}

The destructive processes observed today in all spheres of public life in the vast majority of economies in the world have greatly raised the question of mechanisms capable of delivering sufficient growth rates both in individual countries and in the global economy as a whole. Therefore, it is necessary to look at the problem of development of the economy and society from a fundamental point of view, since the functioning of any system must be based on the basic principles that are manifested in all areas of our lives. Therefore, the study of the constitutional principles of the functioning of the economic system of Ukraine is an outstanding scientific problem and an interesting practical task. It should be noted that this topic is equally relevant from both theoretical and practical point of view. At the same time, these processes are influenced by the socio-economic, political and other consequences of the current global

\footnotetext{
Corresponding author:

${ }^{1}$ SHEI «Uzhhorod National University», Ukraine.

E-mail: belov dimon@yahoo.com

ORCID: https://orcid.org/0000-0002-7168-9488

${ }^{2}$ Yaroslav Mudryi National Law University, Ukraine.

E-mail: Sydorenko1200@gmail.com

ORCID: https://orcid.org/0000-0003-0485-6431
}

financial and economic crisis, which has an objective nature and a number of interrelated prerequisites. The consequences of the current economic recession prompt us to revise existing "classical" theories or doctrines, and, perhaps, abandon them. Last but not least, this concerns issues related to the perennial state-market or power-to-business controversy. It is in this context that the constitutional foundations of the economic system of Ukraine's transformational economy should be considered.

Constitutional and legal norms undoubtedly have a significant impact on the economic system of any state. Models of the world economic systems are established and guaranteed by a system of legal means, which, in turn, are subject to the constitutional and legal framework. The sphere of constitutional and legal regulation of economic relations has been repeatedly explored in scientific research, however, the consensus 
on the scope of economic issues that should be subject to constitutional entrenchment has not been reached yet. The analysis of the world constitutional practice shows a tendency of strengthening the regulation of those relations that concern the economic organization of public life. This topic is relevant since not only the legal theory but also political practice enters into a heated debate over the above-mentioned issue.

\section{Property as a basic category of constitutional and legal regulation of economic relations}

Research of historical facts testifies to the fact that the property relations constitute the basis of the economic system of any social formation. For this reason, they are among the first to be documentarily enshrined. The development of society also entails the development of various forms of property - from tribal and communal to the private one.

Constitutional regulation of property relations is one of the types of legal regulation of property, the basic one for the modern legislation of any country. The science of constitutional law includes a certain set of property conceptions that are specific to it. The analysis of this set of ideas allows scholars to interpret property as one of the most crucial constitutional and legal institutions (Shershun, 2016).

The development of both the economic and legal systems of the European countries has had its impact on the processes of forming an understanding of property; the legal regulation of property as a universal institution has also developed and changed. A characteristic feature of the early historical period of the world civilization was the fragmentation of the institute of property into special types of relations of property ownership, use and disposal with respect to individual subjects and objects. There was the so-called "domination" of the collective property of communities, coupled with the restriction of turnover between such communities. Thus, while the circulation of goods was quite simple and based on existing customs within a community, outside it - between communities - this exchange was rather infrequent and could concern only deficit things. Lifestyle and limited needs did not encourage community members to a constant search.

Historically, the dominance of individual forms of property has always been a priority. For instance, the policy of the Soviet authorities was aimed at eradicating private property as such. This is evidenced by the fact that on December 8, 1961, the Supreme Soviet of the USSR approved the Fundamentals of Civil Legislation of the USSR and the Union republics, which emphasized that the Soviet state is the owner of all state property. The 1977 USSR Constitution enshrined the dominance of socialist property; thus Article 10 stipulated that: "the basis of the economic system of the USSR is the socialist ownership of the production means in the form of state (public) and collective farm-cooperative ownership". A clear list of personal property objects was documented: household items, personal consumption and utility household items, a residential house and labor savings. The obvious weaknesses in the economy spurred the expansion of the rights of enterprises and increased private citizen initiative. The necessity arose to legalize property other than "state" one but also does not fall under the classification of "private" property.

The Basic Law "On Property in the USSR", adopted in 1990, and subsequent amendments to the Constitution contain a waiver of the priority of state property. Various variants appeared: property of Soviet citizens; collective property represented by rental, collective enterprises, cooperatives, joint-stock companies, etc.; state property (Gluhova, 2012). The 1990 Law "On Property in the RSFSR" envisaged division of property into private, state, municipal and public associations (organizations). The permissible "size" of private property was not limited, although certain restrictions were also stipulated (e.g., the private property of land).

With the dissolution of the USSR, the influence of the private property institution on the economic system increased. Thus, after the Soviet rule of state property, the economy gradually began to be absorbed by private property. A drastic step towards introducing market economy principles was the privatization of state property. R.A. Dzhabrailov writes: "Perhaps the state expected to get some synergetic effect from the appearance of private property rights in the structure of objects, which consisted in attracting investments into modernization of production, construction of new objects, improvement of the quality of enterprise employees' social security". However, as we can observe, those events did not bring the expected results. The idea that the market economy and private property were guaranteed to ensure the welfare and prosperity of the people became a de facto dogma. On the contrary to this, the financial crisis of 2008 forced the world to draw other conclusions, in particular, to abandon the thesis that it is possible to provide a systematic and balanced economy of any state with exclusive self-regulation of the market, which is deprived of state guardianship (Ustimenko, 2011).

\section{Main functions of the state and its involvement in the economic system}

Walter Eucken, the founder of the School of Ordoliberalism, believed that "social justice should be sought through the creation of a cumulative functional order... It must be understood that private property can cause disruption, the collective property must cause disruption" (Nureev, 2007). That is, W. Eucken believed that all forms of property should be involved to ensure the full economic development of the state.

In his works, Eucken harshly criticized the so-called laissez-faire: the principle of state non-interference in 
the economy. It was the laissez-faire policy that, in his opinion, caused a significant strengthening of power structures in the economy. W. Eucken believed that the laissez-faire principle underestimates the danger that an individual interest may turn against a common interest. The freedom to conclude contracts within the framework of the liberal order, in his opinion, leads to the denial of the basic principle of the competitive order. An individual interest, as he noted, is realized not only in the economic process but also in forming a position in the market in a certain form. Acquiring positions of power on the market comes into conflict with the common interest. In fact, "the more power is in the hands of individuals, the greater the danger that there will be a conflict between individual and public interests" (Dementev, 2003).

Scholars' research on the system of power in the social and economic system allows drawing a conclusion that the latter includes the following basic institutions as state power, user power and industrial power (corporate power).

State power in the economic system has the following construction logic. The Constitution of Ukraine, in particular, Paragraph 2 of the Article 5, establishes the provisions that people are the bearers of sovereignty and the only source of power in Ukraine. The people exercise power directly and through State and local authorities. In the scientific literature, there is a definition of the State as an organization with a comparable advantage in terms of using violence and extends to a geographical territory the boundaries of which are defined by the authorities of that organization to tax people who reside there (Eggertsson, 2001).

The state embodies a deliberately created, organized and consciously controlled power (Hajek, 2001). Formalization of the notion of "state power" is associated with a certain range of substantive problems. By its nature, the power of the State is delegated, such power acting on the basis of a social contract enshrined in the Constitution and other legislative acts. The main functions of the state, which should ensure the effective operation of the economic system, include integrative, motivational, social control, regulatory, unifying, repressive, stabilizing functions (Chehovich, 2005).

Based on the analysis of these functions, it can be concluded that the potential of state power is based on control over violence resources, ownership of economic resources (budget, state property) and ideological influence, while the power potential of the state is fixed in normative acts in the form of rights of power in relation to citizens and legal entities (Shershun, 2016).

Some scientists, in particular, V.V. Dementev believe that the power exercised by the state can be divided, firstly, into an arbitration power, the essence of which is to protect rights and freedoms of some citizens from arbitrariness on the part of others (i.e. protection of property rights and contracts), secondly, into hierarchical (administrative) power, based on the right of the state to issue prescriptions (norms) regulating public conduct and the right of control over their implementation, and thirdly, into economic power, which is to dispose of economic resources of the state. A state is an organization that exercises authority countrywide. The state exercises power through the so-called mechanism of the state: the system of bodies and institutions that constitute its organizational and political, organizational and economic basis, that is, through public authorities, social institutions, as well as through the budget system, banking, monetary and other economic structures. The boundaries of state power for various objects of power are regulated by legal norms (Dementev, 2003).

The state guarantees the exclusive property rights of individuals, groups and organizations, establishes fundamental rules of economic activity, creates and ensures observance of economic and civil rights (including those of state bodies). The Constitution of Ukraine stipulates that the State ensures the protection of the rights of all property rights holders and subjects of economic activity and the economy social orientation. All subjects of property rights are equal under the law. It should be noted that in the domestic scientific literature, the issue of state regulation of the economy has traditionally been considered through the prism of state functions, in particular, such as economic and organizational, regulation of labor and consumption. Scientists note that it is possible to interpret the state functions not only as directions of its activity but also as a mechanism of influence on social processes (Melnikov, 2011). For example, according to N. Salishcheva, it was not taken into account in the process of reforms that "when proclaiming the freedom of private property, the state should have taken care of the protection of private production and property, of a reasonable system of taxation, of effective legal regulation" (Bachilo, 2001).

A. Komarov understands the state regulation of the economy as the system of economic, legal, organizational measures of the state, through which it influences the socio-economic development of the country and conducts socio-economic public policy through the system of government agencies and officials (Komarov, 2000).

N.I. Bazilev mentions the following economic functions of the state: improvement of the system of socio-economic relations; forecasting of development; demographic management; orientation of production on the final results; elaboration of development programs; increasing the role of labour collectives; coordination of interests of subjects; promotion of economic activity; ensuring intellectual development, protection of life and human rights and freedoms; regulation of international integration processes.

V.I. Kushlin offers the following list of economic functions of the state: legal support of economic activity; 
organization of monetary circulation; production of public goods and services; minimization of transaction costs; minimization of externalities; realization of national interests in the world economy; regional and social policy implementation (Karetnikov, 1998).

I.L. Sokolova notes that the economic function of the state can be defined as the directions of state activity in the economic sphere aimed at ensuring economic growth, the stability of the national economy, foreign economic stability, means and ways of state influence (Sokolova, 2005).

R. Savatier introduced the notion of "economic public order" into the scientific community: "Public order is aimed at solving three tasks: firstly, to protect individual freedom, then to ensure the sovereignty of the state and the strength of the family, and finally to observe the general rules of morality" (Savatier, 1972). As a result of a significant expansion of public authority functions, two new areas of public policy application emerged: social public policy aimed at mitigating class inequality and economic public policy aimed at creating a controllable economy.

Based on the aforementioned material, we have come to the conclusion that the economy of any country needs state regulation to some extent.

\section{The norms of the constitution and the content of the state economics regulation}

Constitutional and legal regulation defines the boundaries and content of state regulation of the economy. The content of constitutional and legal regulation of the system of certain social relations is determined by the circle of relations enshrined in the Basic Law of the State. Economic relations encompass a wide range of social relations, and primarily concern property relations.

The notion of the right of private property found its fixation in the articles of the Constitution of Ukraine. In particular, Paragraph 3 of the Article 13 states that: "Property entails responsibility. Property shall not be used to the detriment of the person and society". This thesis is true, since despite a rather rigid definition of the concept of property right adopted as a basis in the Civil Code of Ukraine: the ownership right is the right of an individual in a thing (property) that he/she enjoys in compliance with the effective legislation on his/her own will irrespective of the will of the third persons; the legislator understands the importance of excessive absolutization of individual person's property right.

M. Andreeva writes that: "During the 20th century, the idea of the social function of private property was spread and further developed in the countries of Western democracy and states oriented towards them" (Andreeva, 2009). The justification for this pheno-menon was first provided by the French lawyer
L. Duguit.He believed that the state appropriates property, which should perform a social function. L. Duguit argued that property is socialized and ceases to be an absolute right and is transformed for the owner into a social debt. The theory of social functions in no way endeavours to neutralize certain rights of the owner. L. Duguit noted that: "...the right of the owner is justified and at the same time is limited by the social mission that lies upon him/her by virtue of the special situation in which he/she is placed" (Ustimenko, 2011). The development of the theory of the social function of property in tandem with the development of information technologies had a huge impact on the development of constitutional regulation of property. They gave rise to changes in the range of relations of constitutional regulation and the inclusion of a large number of objects of intellectual property rights.

In 1960, the ideas of the social functions of property were embodied by nationalizing the most profitable enterprises. The development of the concept of Bolivarianism, the so-called socialism of the XXI century, also made its corrections in the constitutional and legal regulation of property relations. According to this conception, private property was subject to even harsher restrictions, and broad nationalization was implemented (this applied mainly to oil production facilities). Such ideas have given the world the Constitution of Venezuela and other Latin American countries.

Nevertheless, the modern constitutional regulation includes the imprints of the historical development of the concept of property. A number of countries have provisions in their constitutions that enshrine different types of property of different origins. However, the majority of home scholars pay attention to the norms that relate exclusively to the legal regulation of private property, its protection from illegal encroachments and provisions on the exclusive property of the state.

The analysis of the world's constitutions shows that property not only provides rights, but also entails responsibilities. Thus, for example, Article 14 of the German Constitution stipulates: "Property entails obligations. Its use shall also serve the public good".

As we have noted earlier, the Constitution of Ukraine also contains a norm about the obligatory nature of property. However, it is not clear to what obligations it exactly entails. Thus, V.A. Ustymenko writes that: "Ownership binds all subjects of law irrespective of their legal status and the scope of their powers. The obligation to align their actions and aspirations with the principles of civil society and the interests of the people is equally important for both the private and public owner" (Ustimenko, 2011). It is impossible to disagree with this thesis, since only in this way the idea of social functions of property and social orientation of economy, enshrined in the Constitution of Ukraine, can be embodied. 
Returning to the problem of the necessity of the economy state regulation, it should be noted that many scientists, in particular, V.V. Melnikov believes that the complex constitutional regulation of the state's economic role is an exception rather than a general rule in the world practice of constitutionalism (Melnikov, 2011). Thus, in addition to general social formulas, real economic objectives must be established in order to achieve the goal. The Spanish Constitution, for instance, contains provisions according to which wealth of the whole country is subject to the general interests of the country. The Italian Constitution states that private economic initiative is free. It may not be exercised in contradiction with the public interest or at the expense of security, freedom, human dignity. The law defines programmes of activities and control through which public and private economic activities can be directed and coordinated for social purposes. The law defines measures and control programmes through which public and private economic activities can be directed and coordinated for social purposes (Shershun, 2016).

In the world's modern constitutions, it became necessary to establish norms regulating the limits of nationalization of citizens' property as well as compensation of the latter. These provisions are considered to a greater extent as a safeguard against illegal expropriation of the property of a law-abiding owner. Thus, for example, Article 21 of the Constitution of Georgia stipulates: "The restriction of the rights shall be permissible for the purpose of the pressing social need in the cases determined by law and in accordance with a procedure established by law. Deprivation of property for the purpose of the pressing social need shall be permissible ... only with appropriate compensation".

Part 2 of the Article 21 of the Polish Constitution provides as follows: "Expropriation may be allowed solely for public purposes and for just compensation".

The constitutions of individual countries stipulate in great detail the issues of property expropriation. Thus, the Basic Law of Greece directly defines not only the possibility of the state to expropriate property in the public interest, but also details the procedural process for recovering its value: "No one shall be deprived of his/her property except for public benefit which must be duly proven, when and as specified by statute and always following full compensation corresponding to the value of the expropriated property at the time of the court hearing on the provisional determination of compensation. In cases in which a request for the final determination of compensation is made, the value at the time of the court hearing of the request shall be considered" (Konstituciya, 1975).

Any change in the value of expropriated property occurring after publication of the act of expropriation and resulting exclusively there from shall not be taken into account.

Compensation is determined by the competent courts, such compensation may also be determined provisionally by the court after hearing or summoning the beneficiary, who may be obliged, at the discretion of the court, to furnish a commensurate guarantee in order to collect the compensation, as provided by the law. There is also a very important provision for the alienation of property in compensation: "Prior to payment of the final or provisional compensation, all rights of the owner shall remain intact and occupation of the property shall not be allowed". In other words, the legislator at the constitutional level guarantees the inviolability of the right to private property and provides the owners with the means of its protection.

Compensation in the amount determined by the court must in all cases be paid within one year and a half at the latest from the date of publication of the decision regarding provisional determination of compensation payable, and in cases of a direct request for the final determination of compensation, from the date of publication of the court ruling, otherwise the expropriation shall be revoked ipso jure. The compensation as such is exempt from any taxes, deductions or fees.

Constitutions of post-Soviet states usually do not regulate this issue in such detail.

Thus, Paragraph 3 of the Article 25 of the Constitution of the Russian Federation states that no one may be deprived of property otherwise than by court decision. Forced confiscation of property for state needs may be carried out only on the proviso of preliminary and complete compensation.

In contrast to the Greek Constitution, the issue of compensation for expropriated property is not regulated by the Basic Law of the Russian Federation, and therefore it is necessary to resort to the federal legislation of the country for its solution. B. Melnikov writes that a person's deprivation of his/her property by court decision (in the form of a sentence or resolution) can only take place in the cases provided by law (Melnikov, 2011). An exclusive list of the grounds for compulsory expropriation of property from its rightful owner is contained in Paragraph 2 of the Article 235 of the Civil Code of the Russian Federation. In particular, so far, the grounds include: the turning of the penalty onto the property by the obligations; the alienation of the property, which by force of the law may not be owned by the given person; the alienation of immovable property in connection with withdrawal of a land plot because of its improper use; the alienation of an incomplete construction object in connection with termination of the validity term of an agreement on lease of a land plot which is under state or municipal ownership; the alienation of immovable property in connection with compulsory alienation of a land plot for state or municipal needs (withdrawal of a land plot for state or municipal needs; the redemption of the mismanaged cultural values and of domestic animals; the requisition; the confiscation; appropriation on the 
basis of a court decision by the Russian Federation of the property in respect of which any evidence proving its acquisition with the use of lawful income are not presented in compliance with the anticorruption legislation of the Russian Federation; appropriation on the basis of a court decision by the Russian Federation of the monetary assets, valuables, other property and the income derived from them in respect of which in compliance with the legislation of the Russian Federation on counteracting terrorism a person has not presented data proving the legality of their acquisition (Melnikov, 2011).

In addition to the above-mentioned issues, the texts of foreign constitutions have many other provisions regarding the regulation of property relations. These are, in particular, the regulations on the protection of the country's cultural heritage and nature, the regulations on the right of ownership of land, water and other natural resources, on the rights of public organizations, on guarantees of the right of ownership in legal proceedings (objects of ownership of individuals and legal entities); on freedom of conscience and the rights of religious organizations (objects of property rights of religious organizations), the legal status of foreigners, the protection of intellectual property, the right of ownership of the mass media, separate "forms" of ownership, the division of competencies of the federation and the subjects on property issues, the competencies of municipalities on property issues, special regulation of property based on the status of indigenous peoples, etc. Nevertheless, these norms are not comprehensive, they have limitations that define the limits of this study (Shershun, 2016).

Paragraph 5 of the Article 41 of the Constitution of Ukraine contains a provision stating that the expropriation of objects of the right of private property may be applied only as an exception for reasons of social necessity, on the grounds of and by the procedure established by law, and on the condition of advance and complete compensation of their value. The expropriation of such objects with subsequent complete compensation of their value is permitted only under conditions of martial law or a state of emergency.

Therefore, based on the practice of foreign countries, the Ukrainian legislator defined clear boundaries of such expropriation and enshrined guarantees of property rights.

The legislation of Ukraine provides for such types of forcible alienation as requisition (Art. 353 of the Civil Code of Ukraine) and confiscation (Art. 354 of the Civil Code of Ukraine).

With regard to the concept of nationalization, the current Civil Code of Ukraine does not contain any provisions addressing this issue; only Paragraph 3 of the Article 397 of the Economic Code of Ukraine specifies that foreign investments in Ukraine are not subject to nationalization.
Types of forcible alienation of private property are a measure of influence of the state on economic activity within the framework of market mechanism. Defining the boundaries of this action is a topical discussion issue in scientific literature. B. Chirkin writes that economic theories and views cannot be established by the state as state or obligatory, and the state cannot declare Marxism or economic liberalism as state economic ideology (Chirkin, 2001). The state must perform its functions through universally recognized values, basic goals of development, democracy and the rule of law. B.N. Topornin expressed the opinion that the constitution should define the "system of coordinates" in which the state "plays its economic function", pointing out also that the constitution may provide instruments of state regulation, including the budget, taxes, export and import privileges (Topornin, 1992).

\section{The scope of constitutional and legal regulation of economic relations}

The sphere of constitutional and legal regulation of economic relations has been repeatedly subjected to scientific research, but there is still no consensus as to which economic issues should be subject to constitutionalizing. Not only legal theory, but also political practice enters into heated debate over the above-mentioned issue.

As we have mentioned earlier, modern constitutions of foreign countries to a greater extent contain regulations on the economic sphere. These are, in particular, provisions on nationalization of socially important sectors of the economy, state monopoly, agrarian reform, economic planning, social justice, fair distribution of public products, etc.

All constitutions of the twentieth century are characterized by a drastic increase in the range of regulations devoted to numerous economic issues, including: forms of the state's participation in economic activity, public restrictions on the freedom of economic activity, etc. Such approach testifies to the growing role of constitutional regulation of economic relations, however, it caused scientists to seek an answer to the question concerning the reason for the increase in the number of constitutional and legal norms of economic content (Shershun, 2016).

The study of the content of constitutions led the researchers to classify the so-called economic norms according to their content. In particular, M. Andreeva, having studied the issue of the scope and content of constitutional and legal regulation of the economy in foreign countries, suggests classifying the constitutional and legal norms regulating economic relations into four groups: the economic basis of individual freedom; the boundaries of individual freedom in the economic sphere; ways of solving social conflicts in the sphere of entrepreneurship; the role of the state, its economic 
policy and competence of state bodies in the sphere of economy (Andreeva, 1991).

In addition, V.E. Chirkin singles out economic relations that are subject to constitutional and legal regulation including property relations, the role of the state in regulating the economy, etc. The main lever is prognostication. Along with the prognostication, V.E. Chirkin notes that many other levers are used to regulate the economy. They include redistribution of the budget, direct stateization (nationalization) of a number of the economy sectors, tax and credit policy, government intervention in labour relations (legal regulation of working hours, vacations, etc.), the creation of special departments and various kinds of mixed companies with the participation of state capital, where government officials and heads of monopolies together resolve issues of economic regulation, etc. (Chirkin, 2001).

V.E. Chirkin is a supporter of the notion of economy socialization. Economic socialization is a link in the general process of socialization, it "finds its expression in the formation and development of a trend, and subsequently a pattern, according to which under the influence of the producer's needs, the process of assimilation and use of a specific system of knowledge, norms and values necessary for the successful functioning of the national economy, social and economic relations, society as a whole, is accelerated". According to other interpretations, socialization is the development and strengthening of social orientation in the development of economic systems, in which a certain part of net monetary income is used to meet the social, material and social and spiritual needs of the main subject of the economy: the individual. S. Mochernij presents socialization of economy as "a process of gradual evolutionary filling of subsystems and elements of the economic system of capitalism with socialist content, formation and development of the basis of socialism" (Mochernij, 2007).

I.A. Alebastrova writes in her studies that constitutions of the 20th century are characterized not only by socialization, but also by expansion of the circle of constitutional regulation. According to the scholar, the Constitutions "began to regulate not only the foundations of the state's structure, but also the foundations of the construction of civil society, to formulate the objectives and principles of state action in the social sphere, and to regulate, in addition to personal and political rights, economic, social and cultural rights of man and citizen". It is obvious that the new social conditions, which necessitate a broader entrenchment of economic institutions in the basic laws of the state, demonstrate the bond between the constitution and the economy that had emerged long before such entrenchment was necessary (Alebastrova, 2000).

Constitutional and legal regulation of economic relations is a dynamic legal phenomenon, which should become an expression of reaction to the processes occurring in the economic system of the state. The economic system of the state, based on its connection with the constitution, has several key definitions. Thus, D.L.Zlatopolskijwrites, "the state's economic system is the most important element of the social order. It is explained by the fact that the concept of "the state's economic system" includes forms of ownership, constitutes the actual basis of social relations, the foundation of life activity of any state" (Zlatopolskij, 2000).

The boundaries of constitutional regulation are also established by determining the degree of importance of certain public relations in the respective public sphere. Thus, E.I. Kozlova refers to the subject of constitutional law in the sphere of economic life of society only those relations that characterize the basic principles of the economy, forms of ownership, indicating that the full legal regulation of economic relations is implemented by civil, economic, financial and a number of other branches of law (Kozlova, 2003).

A broad approach to identifying regulatory links between the constitution and the economic sphere has allowed us to view the economy as an integral element of civil society. The establishment of civil society in Ukraine has to address a two-fold issue: on the one hand, to provide a real opportunity for citizens through various forms of associations to exercise effective influence on the state. On the other hand, the awareness of their responsibility for the formation and implementation of public policy.

The idea of B. Topornin regarding the definition of constitutional limits of economic regulation is very interesting. Thus, the scholar writes that it is necessary to speak only about the most important and essential issues in the Constitution, leaving concretization and development of the proclaimed principles to the branch legislation. In B. Topornin's opinion, the importance of constitutional regulation of economic issues is conditioned by the interests of relations optimization between the state and society and determination of limits of admissible state interference into economy. According to B. Topornin, "Replacing the constitution with the current legislation on such issues in terms of both theory and practice would be as vulnerable as replacing the current legislation with the constitution" (Topornin, 1992).

In the scientific literature there is also a discussion about the theory put forward by O.E. Kutafin, namely: "the most important component of the subject of constitutional law is the group of relations formed in the process of implementation of the main features of state organization of society". Besides, he came to the following conclusion: "The subject of the constitutional law of any state cannot be given once and for all. It depends on the content of the constitution or other fundamental documents in effect in the State at a certain stage of its development. Thus, the discussion that has 
been held for many years on the scope of relations that constitute the subject of constitutional law has no grounds, as their scope does not depend on the identification of certain social relations that constitute the subject of constitutional law, but, as mentioned above, on the will of the state, which gives them a fundamental character" (Kutafin, 2001).

However, some researchers do not support this view. For example, A.E. Kozlova writes that the constitutional law does not enshrine the state leadership in society in one form. Society is independent of the state and stands above it. The relationship between society and the state should be based on the recognition of human freedom and civil society institutions (Kozlova, 2003).

\section{Conclusions}

1. Constitutional law regulates the place of the state in the political system of society and defines the principles of relations between the state and its non-state elements including the ways of resolving conflicts between them, limits of interference or even limits of its activity.

2. The boundaries of constitutional regulation of economic relations should be determined first of all on the basis of considering fundamental relations for the economic system of the state. That is, the limits of constitutional regulation depend on the system of relations that are included in the concept of economic relations. Since no single point of view regarding the definition of "economic relations" exists in the scientific literature, we believe that the basic relations in this sphere, which require constitutional and legal regulation are: freedom of economic activity and its limits; economic space, free movement of goods, services and financial resources; basic provisions for the organization of market economy; property relations, including the fixation of their forms; guarantees and restrictions in relations between economic entities and public authorities.

The above-mentioned provisions cannot be considered separately from each other, because their exclusively complex development will lead to the harmonious functioning of the state economic system. These provisions should be characterized by complementarity, and the lack of regulation of some items will lead to a significant limitation of the content of others. Thus, for example, it is impossible to exercise freedom of economic activity without constitutional regulation of types of ownership or in the absence of a clear mechanism of restrictions on the interference of public authorities in the freedom of economic activity subjects.

3. The system of relations that require legal regulation should also include the establishment of an effective pricing mechanism, the exercise of control over monetary policy, the cancellation of restrictions on foreign trade activities, the development of an effective tax and budgetary system, regulation of financial reporting, etc.

\section{References:}

Alebastrova, Y. A. (2000). Konstytutsyonnoe (hosudarstvennoe) pravo zarubezhnikh stran [Constitutional (state) law of foreign countries]. Moskow: Yurysprudentsyia. (in Russian)

Andreeva, G. N. (1991). Konstituciya i ekonomika $v$ zarubezhnyh stranah: osnovnye parametry reglamentacii. Sovremennoe konstitucionnoe pravo zarubezhny stran [The constitution and economy in foreign countries: the main parameters of regulation. Modern constitutional law of foreign countries]. Moskow: INION - MYuI. Part. 2. (in Russian)

Andreeva, G. N. (2009). Institut sobstvennosti v konstituciyah zarubezhnyh stran i Konstitucii Rossijskoj Federacii [The Institute of Property in the Constitutions of Foreign Countries and the Constitution of the Russian Federation]. Moskow: Norma. (in Russian)

Bachilo, I. L., \& Hamaneva, N. Yu. (2001). Administrativno-pravovoe regulirovanie v sfere ekonomicheskih otnoshenij [Administrative and legal regulation in the field of economic relations]. Akad. pravovoj un-t pri In-te gosudarstva i prava RAN. Moskow: MZ Press. (in Russian)

Belov, D., Gromovchuk, M., \& Blikhar, V. (2019). The Constitution as the Basic Law of the State: Statics and the Possible Dynamics of Development. Challenges and prospects for the development of legal systems in Ukraine and EU countries: comparative analysis: Collective monograph. Riga: Izdevnieciba "Baltija Publishing".

Chehovich, T. V. (2005). Derzhavna vlada yak institut konstitucijnogo prava Ukrayini [State power as an institution of constitutional law of Ukraine]. Avtoref. dis. ... kand. yurid. nauk: 12.00.01. Kyiv. (in Ukrainian)

Chirkin, V. E. (2001). Sovremennoe gosudarstvo [The modern state]. Moskow. (in Russian)

Dementev, V. V. (2003). Ekonomika kak sistema vlasti [Economic as a power system]. M-vo obraz. i nauki Ukrainy, Doneckij nac. tehn. un-t. Doneck: Kashtan. Donetsk. (in Russian)

Eggertsson, T. (2001). Ekonomicheskoe povedenie i instituty [Economic behavior and institutions]. Moskow: Delo. (in Russian)

Gluhova, M. (2012). Sobstvennost v Rossii: uzhe pravo, eshe ne svyashennoe. Promyshlennik Rossii [Property in Russia: already law, not yet sacred. Industrialist of Russia]. Available at: http://promros.ru/magazine/2012/mar/ sobstvennost-v-rossii-uzhe-pravo-esche-ne-svyaschennoe.phtml (accessed 01 December 2019). (in Russian)

Hajek, F. (2001). Individualizm i ekonomicheskij poryadok [Individualism and economic order]. Moskow: Izograf. (in Russian) 
Karetnikov, M. V. (1998). Gosudarstvennoe regulirovanie ekonomiki [State regulation of the economy]. Chelyabinsk. (in Russian)

Komarov, A. (2000). Gosudarstvennoe regulirovanie ekonomiki [State regulation of the economy]. Law and life, no 31, pp. 134-142. (in Russian)

Konstituciya Grecii ot 11 iyunya 1975 goda [Greek Constitution of June 11, 1975]. Available at: http://www.khanukaev.com/ru/Article/61.aspx (accessed 01 December 2019). (in Russian)

Kozlova, E. I. (2003). Konstitucionnoe pravo Rossii [Constitutional law of Russia]. Moskow: Yurist. (in Russian)

Kutafin, O. E. (2001). Predmet Konstitucionnogo prava [Subject of Constitutional Law]. Moskow. (in Russian)

Melnikov, V. V. (2011). Konstitucionnye osnovy regulirovaniya ekonomicheskih otnoshenij v Rossii [Constitutional foundations of regulation of economic relations in Russia]. Moskow: YuRKOMPANI. (in Russian)

Mochernij, S. V. (2007). Politichna ekonomiya [Political economy]. Kyiv: Znannya. (in Ukrainian)

Nureev, R. M. (2007). Socialnoe rynochnoe hozyajstvo: koncepcii, prakticheskij opyt i perspektivy primeneniya $v$ Rossii [Social market economy: concepts, practical experience and prospects of application in Russia]. Moskow. (in Russian)

Savatier, R. (1972). Teoriya obyazatelstv. Yuridicheskij i ekonomicheskij ocherk [Theory of Obligations. Legal and economic essay]. Moskow. (in Russian)

Shershun, K. P. (2016). Konstitucijno-pravove regulyuvannya ekonomichnih vidnosin: porivnyalno-analitichne doslidzhennya [Constitutional and legal regulation of economic relations: a comparative-analytical study]. Disertaciya kand. yurid. nauk zi spec. 12.00.02 - konstitucijne pravo; municipalne pravo. Uzhgorod. (in Ukrainian) Sokolova, I. L. (2005). Osobennosti ekonomicheskoj funkcii federativnogo gosudarstva [Features of the economic function of a federal state]. Legislation and economics, no 5, pp. 9-16. (in Russian)

Topornin, B. N. (1992). Konstitucionno-pravovye problemy formirovaniya novoj ekonomicheskoj sistemy. Konstitucionnyj stroj Rossii [Constitutional and legal problems of the formation of a new economic system. The constitutional system of Russia]. Moskow. (in Russian)

Ustimenko, V. A., Dzhabrailov, R. A., \& Kampo, V. M. (2011). Konstitucijni zasadi ekonomichnoyi sistemi Ukrayini [Constitutional ambush the economic system of Ukraine]. NAN Ukrayini, In-t ekon.-prav. doslidzh. Doneck: Yugo-Vostok. (in Ukrainian)

Zlatopolskij, D. L. (2000). Gosudarstvennoe pravo zarubezhnyh stran [State law of foreign countries]. Moskow. (in Russian) 